\title{
Kaitan Nilai Budaya dan Fakta Sosial Novel Sukreni Gadis Bali Karya AA Panji Tisna
}

\author{
Benediktus Sugiyo \\ Universitas Indraprasta PGRI \\ Jalan Nangka No. 58 C/TB. Simatupang, Tanjung Barat, Jakarta Selatan 12530
}

\begin{abstract}
This study aims to determine the relationship of cultural values and social facts of the novel Sukreni Gadis Bali by AA Panji Tisna. The research method used in this study is a qualitative method. The approach used is semiotic. This research is directed to be able to understand broadly, thoroughly, and more deeply and can obtain meaning from the cultural values and social facts in the novel Sukreni Gadis Bali. Furthermore, this research can be used as a fun teaching material. In this study the authors use literature study techniques by reading books that fit the problem studied so that the books are used as a theoretical basis. The results of this study can be concluded that there is a link between cultural values with social facts Sukreni Gadis Bali novel by AA. Pandji Tisna. This can be seen through the cultural elements in this novel, relating to the social facts of the people.
\end{abstract}

Keywords: Cultural values, social facts, novels.

\begin{abstract}
Abstrak
Penelitian ini bertujuan untuk mengetahui kaitan nilai budaya dan fakta sosial novel Sukreni Gadis Bali karya AA Panji Tisna. Metode penelitian yang digunakan dalam penelitian ini adalah metode Kualitatif. Pendekatan yang digunakan semiotik. Penelitian ini diarahkan untuk bisa memahami secara luas, menyeluruh, dan lebih mendalam serta dapat memperoleh makna dari nilai budaya dan fakta sosial dalam novel Sukreni Gadis Bali. Selanjutnya penelitian tersebut dapat dijadikan bahan ajar secara menyenangkan. Dalam penelitian ini penulis menggunakan teknik kajian pustaka yaitu dengan cara membaca buku-buku yang sesuai dengan permasalahan yang diteliti sehingga buku buku tersebut dijadikan dasar teori. Hasil penelitian ini dapat disimpulkan bahwa terdapat kaitan antara nilai budaya dengan fakta sosial novel Sukreni Gadis Bali karya AA. Pandji Tisna. Hal ini dapat dilihat melalui unsur-unsur budaya dalam novel ini, berkaitan dengan fakta sosial masyarakatnya.
\end{abstract}

Kata Kunci: Nilai budaya, fakta sosial, novel

\section{PENDAHULUAN}

Luxemburg (1991:21) menjelaskan bahwa setiap karya sastra terikat pada waktu dan budaya, karena sastra adalah hasil kebudayaan. Karena itu sastra harus dilihat dalam hubungannya yang tak dapat dipisahkan dengan kehidupan masyarakat, latar belakang unsur sejarah dan sosial yang mempengaruhi pengarang (Jdanov dalam Escarpit, 2017: 8)

Sebuah karya sastra tidak lahir dalam situasi kosong kebudayaannya, termasuk di dalamnya situasi sastra (Teeuw, 1980 dalam Pradopo, 2007:25). Karena itu, karya sastra mempunyai hubungan yang sangat erat dengan sejarah antara karya sezaman, yang mendahuluinya atau yang kemudian. 
Secara umum, sastra merupakan teks rekaan yang nilainya tergantung pada ekspresi jiwa dan kedalaman pikiran. Karya sastra itu pada dasarnya pengolahan bahasa yang sangat indah. Wellek dan Waren dalam Teori Kesusastraan menyatakan bahwa sastra itu menyajikan suatu kehidupan, yang sebagian besar terdiri dari kenyataan sosial, walau demikian sastra juga meniru alam dan dunia subjektif manusia (Dewi, 2015:1).

Dalam Kamus Besar Bahasa Indonesia (2005) Novel adalah karangan prosa yang panjang mengandung rangkaian cerita kehidupan seseorang dengan orang di sekelilingnya dengan menonjolkan watak dan sifat setiap pelaku. Istilah Novel berasal dari bahasa Inggris, masuk dalam kosakata bahasa Indonesia pada dasarnya berasal dari bahasa Italia yaitu novella. Secara harfiah novella berarti sebuah barang baru yang kemudian diartikan sebagai cerita pendek (Abram dalam Nurgiyantoro, 2015: 9). Kutipan tersebut menjelaskan bahwa mulanya diartikan sebagai cerita pendek. Pada perkembangannya novella tidak lagi diartikan sebagai cerita pendek. Saat ini jumlah halaman dalam suatu novel ada yang berjumlah ratusan.

Perkembangan novel di Indonesia cukup pesat, terbukti dengan banyaknya novel baru yang di terbitkan. Novel- novel tersebut memiliki bermacam-macam tema dan isi, antara lain tentang problem-problem sosial yang pada umumnya terjadi dalam masyarakat, termasuk yang berhubungan perasaan dan kejiwaan. Kesusastraan termasuk di dalamnya novel merupakan suatu cara mengungkapkan gagasan, ide, pemikiran dengan gambaran-gambaran pengalaman. Dengan begitu sebuah karya sastra berusaha menggugah kesadaran penglihatan, pendengaran, penciuman, perabaan serta ingin memberikan pengalaman imajinatif bagi pembacanya, inilah yang menyebabkan suguhan gambaran pengalaman yang disajikan sebuah karya sastra membuat pembacanya ingin secepat mungkin menghabiskan bacaan tersebut. Novel terbedakan menjadi novel serius dan novel populer. Dalam novel populer cerita disampaikan dengan gaya emosional, hanya mengungkapkan permukaan kehidupan, dangkal, tanpa pendalaman. Sementara novel serius tidak berhenti pada permukaan saja, tetapi selalu mencoba memahami sesuatu secara mendalam dan mendasar atas suatu masalah (Sumardjo, 1982).

Sumardjo (1986:29), membedakan antara novel dengan roman dengan menyebutkan bahwa novel lebih pendek dari pada roman. Akan tetapi, dilihat dari luas unsur cerita, antara novel dengan roman hampir sama. Anak Agung Pandji Tisna adalah salah satu sastrawan yang berasal dari Bali. Beliau termasuk sastrawan tingkat nasional yang cukup terkenal. Beberapa karyanya banyak mendapat perhatian masyarakat Indonesia, khususnya masyarakat sastra. Beberapa karya sastra berupa novel yang pernah ditulisnya yaitu: 1) Ni Rawit Centi Penjual Orang, 2) Sukreni Gadis Bali, 3) Dewi Karuna, 4) Made Widiadi, 5) I Swasta Setahun di Bedahulu.

Dari sekian banyak novel karangan AA Panji Tisna, Sukreni Gadis Bali adalah yang menarik perhatian penulis. Kelebihan novel ini karena isinya mengajarkan kepada pembacanya untuk selalu berbuat baik seperti diceritakan oleh Luh Sukreni. Luh Sukreni adalah sosok manusia yang ditampilkan sangat bersahaja, setia akan ajaran agama. Luh Sukreni adalah nama tokoh atau sosok perempuan yang tangguh. Ia sangat percaya akan karma sehingga tidak melenyapkan bayi yang dikandungnya walaupun bukan berasal dari benih cintanya.

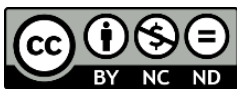

Creative Commons Attribution-NonCommercial-NoDerivatives 4.0 International License 
Ia mewakili wanita Indonesia pada umumnya dan kaum wanita Bali pada khususnya yang pada waktu itu masih memiliki derajat yang rendah. Karena itu wanita Bali pada zaman itu bisa di "permainkan" oleh oknum pejabat negara. Sebagai ketua raja-raja di Bali, AA Panji Tisna mengerti betul akan budaya, fakta sosial serta seluk beluknya. Demikian juga tentang karma, sangat memahaminya. Sehingga mampu menyajikan cerita ini sebagai cerminan masyarakat pada zamannya.

\section{METODE}

Penelitian ini dilakukan bulan September 2018 sampai dengan Januari 2019. Penelitian ini termasuk dalam penelitian kepustakaan. Oleh karena itu, penelitian dilakukan di perpustakaan, yaitu Pperpustakaan Universitas Indraprasta PGRI. Untuk menambah khazanah pengetahuan, penulis juga melakukan penelitian di Perpustakaan Universitas Sanata Dharma Yogyakarta selaku kampus almamater, perpustakaan Nasional di Jakarta, perpustakaan sekolah SMP Santa Angela Bandung, serta perpustakaan pribadi yaitu di Graha Bukit Raya I Blok e4 no:5, Kelurahan Cilame, Kecamatan Ngamprah, Kabupaten Bandung Barat, awa Barat.

Metode penelitian yang digunakan dalam penelitian ini adalah metode Deskriptif Kualitatif. Pendekatan yang digunakan semiotik. Penelitian ini diarahkan untuk bisa memahami secara luas, menyeluruh, dan lebih mendalam serta dapat memperoleh makna dari nilai budaya dan fakta sosial dalam novel Sukreni Gadis Bali. Selanjutnya penelitian tersebut dapat dijadikan bahan ajar secara menyenangkan. Adapun yang menjadi sumber data dalam penelitian ini adalah novel yang berjudul Sukraeni Gadis Bali karya A A Panji Tisna yang diterbitkan oleh Balai Pustaka tahun 2013.

Dalam penelitian ini penulis menggunakan teknik kajian pustaka yaitu dengan cara membaca buku-buku yang sesuai dengan permasalahan yang diteliti sehingga buku-buku tersebut dijadikan dasar teori.

\section{HASIL DAN PEMBAHASAN}

\section{Analisis Nilai-Nilai Budaya}

\section{Nilai Budaya tentang Kesopanan}

“Akan masuk ke situ, mesti melalui sebuah pintu bambu dahulu." (hal.1)

Melalui cakapan dalam setiap tokoh, novel ini juga menanamkan nilai-nilai budaya tertentu pada pembacanya. Nilai yang pertama terlihat adalah tentang kesopanan, yaitu sopan-santun yang ditunjukkan oleh tokoh dalam hal tata cara masuk rumah orang. Di sini diajarkan sopan santun jika seseorang memasuki rumah orang lain, maka haruslah melalui pintu, sekalipun pintunya itu tidak bagus. 


\section{Diskursus: Jurnal Pendidikan Bahasa Indonesia}

Vol. 2, No. 3, Desember 2019, pp. 204-215

p-ISSN: 2615-4935

e-ISSN: 2615-4943

Nilai Budaya tentang Bekerja Sama Atau Gotong-Royong

"Jalan kecil itu ramailah jika orang desa turun bekerja rodi atau datang berkumpul ke balai desa di Kampung Bunut Panggang, sebuah kampung yang terletak di pinggir jalan raya dan penduduknya beragama Islam.“(hal. 1)

Selain nilai kesopanan yang telah disebutkan dalam bagian di atas, nilai budaya lain yang dimunculkan adalah nilai budaya tentang bekerja sama. Pada bagian awal Sukreni Gadis Bali ini, dimunculkan tentang nilai budaya bekerja beramai-ramai. Istilah tersebut sering kita namakan gotong-royong. Gotong royong adalah bekerja bersama-sama untuk kepentingan bersama.

\section{Nilai Budaya tentang Minum Bersama Sebelum Bekerja}

“Ada bayuan, Emak?” tanya seseorang dengan membau-baui guci tuak.” (hal.7)

Budaya minum bersama di Bali merupakan hal yang biasa, apalagi kegiatan minum tersebut dilakukan sebelum orang mulai bekerja. Biasanya mereka minum tuak sebagai tanda kebersamaan. Hal ini diperlihatkan oleh para pegawai kebun kelapa, yaitu para pemetik kelapa milik Ida Gde Swamba. Minuman yang terkenal disebut bayuan, yaitu tuak yang telah bermalam.

"Men Negara sibuk menuangkan tuak bayuan ke dalam beberapa gelas yang amat kotor untuk tukang-tukang panjat itu. Demikianlah mereka minum-minum beramairamai dahulu untuk menguatkan badan sebelum memanjat." (hal. 9)

Selain sebagai tanda kebersamaan, tradisi minum tuak atau bayuan sebelum bekerja, juga dipakai sebagai penguat badan agar dalam bekerja bisa kuat yaitu memanjat pohon kelapa. Berikut cuplikan yang penulis temukan.

\section{Nilai Budaya tentang Gotong Royong}

"Dengan pertolongan dua puluh lebih mudahlah kereta itu keluar dari lumpur, lalu meneruskan perjalanannya." (hal.11)

Kehidupan bergotong-royong sudah ditunjukkan pada jaman dahulu. Hal ini dapat kita lihat dari sikap Men Negara yang menyuruh para pekerja kebun kelapa untuk ikut membantu kereta yang masuk dalam lumpur. Nilai kebersamaan yang dimunculkan untuk menunjukkan bahwa segala sesuatu jika dilakukan secara bersama, menjadi sangatlah mudah.

Nilai Budaya tentang Menghormati Orang Lain dengan Minum Kopi

"Marilah ratu dengan saya pergi ke warung itu minum kopi dahulu," kata I Gusti Made Tusan dengan hormat. (hal.20)

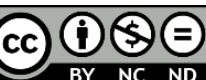


Masyarakat di Bali juga mempunyai kebiasaan yang baik dalam menghargai orang lain. Kebiasaan itu berupa minum kopi. Ini dapat dilacak dalam percakapan antara I made Tusan dengan Ida Gde. Hal ini membuktikan bahwa budaya minum kopi digunakan sebagai sarana untuk mengakrabkan diri.

\section{Nilai Budaya tentang Kesetiaan / Turut Pada Atasan}

"Dengan hati mengkal I Made Aseman terpaksa mengiringkan tuannya ke kedai, yang dihindar-hindarkan." (hal.31)

Novel ini juga memberikan teladan tentang kesetiaan, yaitu setia atau taat pada atasan. Teladan ini ditunjukkan oleh I Gusti Made Tusan sebagai menteri polisi di daerah tersebut. I Made Aseman adalah anak buah dari I Gusti Made Tusan. Sebagai anak buah, tentunya apa yang diperintahkan atasan, maka harus dituruti. Hal ini terjadi dalam dinas militer atau kepolisian. Sebagai mata-mata kepolisian, I Made Aseman tidak boleh melawan atasan. Ini menunjukkan loyalitas dalam tugas sebagai abdi negara. Seandainya tidak sesuai dengan hati nurani pun, harus dijalankan.

\section{Nilai Budaya tentang Menyelesaikan Pekerjaan Secara Tuntas}

"Silakanlah Ratu dulu ke situ, saya sebentar lagi, jika kelapa sebagian kebun ini telah turun semuanya," sahut Ida Gde dengan hormatnya." (hal.20)

Masyarakat Bali juga sangat percaya akan karma, karenanya dalam mengerjakan sesuatu haruslah dilaksanakan secara tuntas. Jika seseorang dalam mengerjakan sesuatu tidak tuntas maka akan berdampak tidak baik. Budaya ini sangat baik karena mengajarkan pada kita bahwa tidak baik mengerjakan sesuatu hanya setengah-setengah. Dalam Sukreni Gadis Bali, nilai budaya ini dijelaskan oleh percakapan antara Ida Gde Swamba dengan I Gusti Made Tusan.

Nilai Budaya tentang Kesopanan Sebelum Nikah Tidak Boleh Bermalam Bersama.

"Aduhai Kandaku, jangan, jangan. Betapa juga rindu Dinda melihat Kanda bermalam di sini, tapi wajib pergi dengan pasti, yaitu jangan menurut kabar angin saja...." (hal.33)

Masyarakat Bali sangat menghargai kesucian. Demikian juga dalam kehidupan sehari-hari selalu berpegang pada perilaku yang suci. Termasuk dalam hal ini, ditunjukkan oleh perilaku I Ketut Rai, sebagai tokoh tidak utama dalam novel Sukreni Gadis Bali. Masyarakat Bali menganggap hal yang tabu jika seseorang belum menjadi suami istri tetapi bermalam di rumah calon jodohnya. Jika hal ini dilanggar maka akan mengakibatkan dosa. Dalam novel ini, dideskripsikan antara tokoh Ni Negari sebagai anak dari Men Negara, dengan I 
Ketut Rai sebagai kekasih Ni Negari.

Nilai Budaya tentang Musyawarah Bukan Berdasar Isu

"Begini saja , Pan Luh, nanti saya berkirim surat kepada kakak saya Penggawa, supaya ia memberi nasihat atau keterangan kepada Balai Kerta, bahwa janganlah orang mati dijadikan contoh dalam perkara itu. Lebih baik kerama desa berkumpul serta memutuskan dengan suara terbanyak, masih dianggapkah orang Bali anaknya yang sudah masuk agama lain, jadi ahli warisnya?" (hal.48)

Masyarakat Bali terbagi-bagi secara otonom menjadi wilayah-wilayah yang kecil, yang disebut desa, yang diketuai oleh Kelian. Kelian bertugas menangani masyarakat dari segala hal. Baik itu berupa perlindungan, keamanan, keadilan, serta kesejahteraan masyarakatnya. Bila terjadi perselisihan maka diselesaikan di Balai Kerta. Dalam pembicaraan antara Ida Gde dengan I Gusti Made Tusan, dijelaskan bahwa I Gusti Made Tusan yang sangat berharap akan bisa menolong Luh Sukreni, mulai menyangkut-pautkan dengan agama. Hal ini tidak disukai oleh Ida Gde, karena bukan saatnya lagi membicarakan isu agama. Akan tetapi, karena masalah diawali oleh orang yang beragama lain maka dipotonglah pembicaraan itu oleh Ida Gde.

\section{Nilai Budaya Tentang Menghargai Orang Lain Sebagai Saudara}

"Bermalamlah di sini barang beberapa hari dan anggaplah Ni Negari sebagai adikmu." (hal. 59)

Budaya masyarakat Bali sangat kekeluargaan karena menganggap semua orang adalah saudara. Ini terjadi karena budaya masyarakat Bali yang bisa dengan mudah beradaptasi dengan lingkungan yang baru. Dalam hal ini, yaitu Sukreni Gadis Bali karya AA Pandji Tisna, ditanamkan ajaran tentang nilai-nilai budaya yang nampak. Nilai-nilai tersebut bisa juga muncul dari tokoh utama maupun tokoh ke tiga. Apa pun nilai yang muncul adalah anggapan tentang saudara bagi masyarakat yang menjadi teman. Apa lagi orang tersebut adalah perempuan. Dalam novel ini ditunjukkan melalui percakapan antara tokoh utama Luh Sukreni dengan Men Negara.

\section{Nilai Budaya tentang Mengubah Kebiasaan Tidak Secara Mendadak}

"Benar sekali terkamu. Ya, karena itulah. Jika ia kemari, terharulah hatinya melihat kedai ini. Engkau tahu, beberapa hari yang lalu aku menerima surat darinya, ia melarang aku dan engkau makan makan di kedai ini. Namun, supaya jangan tampak perubahan, aku hendak berbuat perlahan-lahan. Siapa tahu, jika kita pindah makan dengan tergesa-gesa dari sini, tak baik jadinya pada diri kita kelak," bisik I Mujana (hal.74) 
Percakapan antara I Kantor dengan I Mujana dalam novel Sukreni Gadis Bali ini, walaupun bukan merupakan tokoh utama, dapat digunakan sebagai wujud sifat masyarakat Bali. Adapun percakapan tersebut menjelaskan tentang nilai budaya yang ditonjolkan oleh tokoh tersebut yaitu nilai budaya tentang cara mengubah kebiasaan secara mendadak. Yaitu supaya jangan meninggalkan kedai sebagai langganan secara mendadak. Hal ini akan berakibat tidak baik kelak kalau tiba-tiba meninggalkan kedai. Walaupun kedai tersebut telah menjadi saksi kebiadaban orang yang terpandang yaitu seorang menteri polisi.

\section{Nilai Budaya Penguatan Kepada Orang yang Menderita Atau Silih Asih.}

"Setelah anak itu dilihatnya, pergilah I Gde ke hotel kembali. Ia sudah memberi nasihat kepada Luh Sekreni sekali lagi, bahwa ia harus kuat dan tegap menurutkan aliran kehidupan di atas dunia ini dan sabar menanggungkan segala macam cobaan" (hal. 92)

Masyarakat Bali sangat toleran dalam kehidupan sehari-hari. Sebagian besar masyarakatnya beragama Hindu, yaitu agama leluhur yang sangat ditaati. Dalam menjalani kehidupannya pun masyarakat Bali sangat silih asih terutama bagi yang menderita. Novel ini juga mengandung ajaran tentang silih asih yang ditunjukkan oleh dialog antara tokoh utama yaitu Sukreni dengan Ida Gde. Setelah Ida Gde bertemu dengan Sukreni dan mengetahui bahwa Sukreni telah mempunyai anak dari hasil perbuatan yang keji, Ida Gde tidak menganggap itu sebagai kesalahan Sukreni. Bahkan anaknya tidak bersalah, suci, bersih, yang harus dilindungi. Ida Gde Swamba bahkan akan membiayai atau menyokong anaknya. Begitu mulia Ida Gde karena kasihnya kepada Sukreni. Itulah jalan hidup yang harus dilalui Sukreni, kekasihnya.

\section{Analisis Fakta Sosial}

Ngaben adalah ritual bagi masyarakat Bali yang berupa kremasi atau pembakaran mayat yang dipercaya sebagai sarana untuk mengantarkan manusia pada kehidupan selanjutnya. Peristiwa ini juga diartikan sebagai sarana untuk menyucikan roh yang telah meninggal dunia. Dalam novel ini juga disinggung tentang peristiwa ngaben. Hal ini menunjukkan bahwa fakta sosial pun merupakan salah satu bagian dalam karya sastra.

Senteng adalah kain (selendang) penutup dada untuk wanita di Bali. Sedangkan bulang merupakan kain yang dililitkan pada kepala. Apabila perempuan Bali sudah melahirkan anak, biasanya mereka menggunakan senteng agar perut mereka tidak semakin gemuk atau Senteng juga berguna untuk melangsingkan tubuh. Sedangkan bulang sebagai penutup kepala agar tidak kepanasan. Demikian juga dalam novel dideskripsikan tokoh utama yaitu Ni Luh Sukreni sebagai gadis yang memakai santeng.

Fakta sosial yang lain adalah kelian. Kelian merupakan kepala desa di Bali. Tugas utama kelian adalah menjaga dan bertanggung jawab terhadap kedamaian, kemakmuran, keamanan masyarakatnya. Kadang-kadang seorang kelian bisa juga 
menjadi penengah bagi masyarakat yang bersengketa. Secara singkat kelian mempunyai tugas mengurus kehidupan sosial, pemerintahan, keagamaan, dan tidak digaji karena kelian adalah abdi masyarakat, lembaga penyelesaian konflik dikenal dengan sangkepan, Masyarakat yang mendapatkan masalah diselesaikan di balai kerta.

Dalam Kamus Besar Bahasa Indonesia, tuak adalah minuman beralkohol yang dibuat dari nira aren (kelapa, siwalan) yang diragikan . Bayuan adalah sebutan tuak dari Bali yang dibuat dari sadapan air bunga pohon jake (enau) atau nyuh (kelapa) atau ental (lontar/siwalan) dan tuak telah tersimpan dua sampai tiga hari. Tuak ini sering diminum masyarakat Bali sebelum bekerja, agar badan terasa hangat dan badan terasa segar, tetapi kalau kebanyakan akan memabukkan. Dalam novel ini juga dijelaskan oleh penulis tentang kebiasaan masyarakat Bali minum tuak sebelum bekerja terutama bekerja keras memanjat pohon kelapa.

Kata "ratu," bagi masyarakat Bali adalah sebutan atau panggilan untuk orang kepada orang yang dihormati/disegani. Biasanya dihormati karena pangkat, kedudukan dalam pemerintahan. Ratu terdiri dari dua kata bahasa Kawi "Ra" berarti dihormati, dan "Tu"berarti orang. Jadi "Ratu"artinya orang yang dihormati.

Istilah "jero," dalam masyarakat Bali juga sebutan untuk orang yang belum dikenalnya. Jero adalah panggilan kehormatan apabila belum mengenal orang lain yang akan diajak bicara. Masyarakat Bali masih menghormati caturwangsa leluhurnya, kita tidak mengetahui kasta/caturwangsa orang diajak bicara. Oleh karena itu agar orang yang diajak bicara tidak tersinggung maka diawali dengan jero.

\section{Analisis Unsur-unsur Budaya Bahasa}

Bahasa merupakan salah satu unsur kebudayaan, sekaligus menjadi alat perantara yang utama bagi manusia untuk meneruskan atau mengadaptasikan kebudayaan. Bentuk bahasa tersebut adalah bahasa lisan dan bahasa tulisan. Dalam hal ini bahasa dan sastra sangat erat hubungannya. Karena itu keindahan karya sastra tampil dalam pemahaman kata-kata dalam kalimat.

Bahasa merupakan sarana dalam kehidupan sehari-hari. Demikian juga dalam sastra. Bahkan bisa dikatakan bahwa dalam kehidupan sehari-hari mustahil tanpa adanya bahasa. Demikian juga dalam karya sastra khususnya dalam novel Sukreni Gadis Bali karya AA Panji Tisna, dalam penokohannya selalu berbahasa antara tokoh satu dengan yang lainnya

Melihat betapa pentingnya arti bahasa dalam kehidupan sehari-hari, maka dalam Sukreni Gadis Bali ini pun sangat kental dengan pemakaian bahasa antar tokoh. Pemakaian bahasa tersebut terwujud dalam setiap dialog antar tokoh. Dengan ringkas bahasa itu dipakai dalam kehidupan manusia sehari-hari. Baik pemakaian untuk diri sendiri maupun pemakaian bersama dengan orang lain.

\section{Sistem pengetahuan}

Sistem pengetahuan merupakan bagian dari kebudayaan, di dalamnya memuat sistem flora dan fauna, waktu, ruang dan bilangan, tubuh manusia, dan perilaku antar sesama manusia. Sebagai salah satu unsur dari suatu kebudayaan,

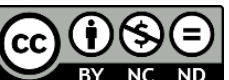


sistem pengetahuan tidak bisa terlepas dari sejarah perkembangannya. Ratna (2011:426), menyebutkan bahwa ilmu pengetahuan berkembang pesat pada abad renaissance yaitu abad ke-15. Dijelaskan bahwa sebelum dan sesudahnya sebagian masyarakat belum bisa membedakan secara jelas antara pengetahuan formal dan informal, pengetahuan yang diperoleh secara objektif ilmiah dengan pengetahuan yang didasarkan atas pengalaman sehari-hari.

\section{Sistem kemasyarakatan}

Demikian pula dalam masyarakat Bali yang diceritakan melalui tokoh utama dalam Sukreni Gadis Bali juga sudah mengenal pengetahuan informal. Pengetahuan ini dapat diketahui dari kehidupan sehari-hari, yaitu tentang adanya tanda-tanda alam tentang hujan. Cuplikan di bawah dapat kita gunakan sebagai acuan tentang patokan oang Bali dalam melihat tanda alam yaitu akan datangnya hujan.

Unsur kebudayaan yaitu pengetahuan juga dapat terlihat dari percakapan tokoh Ida Gde dengan Chatterjee. Percakapan tersebut menandakan bahwa tokoh dalam cerita merupakan seorang yang ahli dalam hal seni.

\section{Sistem peralatan hidup dan teknologi}

Dalam kehidupan manusia, rumah, pakaian, dan berbagai peralatan yang dibutuhkan dalam kehidupan merupakan hasil kebudayaan yang paling awal. Rumah serta pakaian merupakan kebutuhan yang utama yang harus dipenuhi terlebih dahulu. Dalam hal ini dinamakan kebutuhan primer. Selain rumah, yang menjadi pokok peralatan hidup adalah pakaian. Dalam hal ini, novel Sukreni Gadis Bali di dalamnya memuat unsur budaya yang berupa sistem peralatan hidup dan teknologi. Rumah, sebagai hal yang utama bisa berbentuk warung atau kedai menjadi tempat tinggal sekaligus tempat usaha. Tempat tinggal dan berlindung dari hujan, terik matahari, dan sebagainya

\section{Sistem mata pencaharian hidup}

Setiap kehidupan manusia pastinya erat sekali dengan mata pencaharian. Hal ini dilakukan untuk bisa bertahan hidup. Bahkan setiap manusia untuk bertahan hidup harus mempunyai pendapatan yang kontinu. Pendapatan yang kontinu tersebut dipergunakan untuk kelangsungan hidup yaitu untuk kebutuhan yang bersifat jasmani. Mata pencaharian ada bermacam-macam, misalnya bertani, berdagang, berkebun, nelayan, dan sebagainya. Mata pencaharian pertanian sudah dilakukan dari zaman dahulu sehingga dianggap sebagai mata pencaharian yang pertama. Dalam sistem ini juga diciptakan alat -alat untuk bercocok tanam. Bisa terjadi membuat cangkul secara sederhana, golok, sabit, dan yang lainnya.

Dalam perkembangan peradaban manusia, mencapai puncaknya pada zaman modern yang diikuti oleh orientasi dalam hidup. Dengan dibantu kemajuan teknologi, maka peralatan yang sederhana tersebut berkembang sangat pesat menjadi modern.

Dalam masyarakat Bali, membuka warung juga merupakan suatu mata pencaharian. Warung tersebut bisa dibongkar pasang, permanent atau yang lainnya dapat dipergunakan sebagai penopang hidupnya. Hal ini dapat kita telusuri dari 
tokoh Men Negara yang mempunyai mata pencaharian berdagang, dengan membuka warung untuk kehidupannya.

Bali menjadikan dirinya sebagai masyarakat yang hidupnya dari pariwisata. Untuk itu terjadi pergeseran dalam hal mata pencaharian. Barang-barang yang sifatnya rohani juga diperjual-belikan. Hal ini tidak terbatas pada benda-benda budaya yang sifatnya biasa seperti lukisan, patung, benda kerajinan dan sebagainya, tetapi juga upacara adat. Bahkan komoditas perempuan juga digunakan sebagai daya tarik warung Men Negara

\section{Sistem religi}

Sistem religi dalam hal ini sangatlah luas cakupannya. Karena itu yang tergolong dalam sistem religi antara lain menyangkut sistem kepercayaan, sistem nilai dan pandangan hidup, komunikasi keagamaan, dan termasuk juga upacara keagamaan.

Istilah religi ini berasal dari bahasa Latin religio yaitu berkaitan dengan kepercayaan dan keyakinan. Maka istilah ini menyangkut sistem kepercayaan yang berlaku pada masyarakat Bali. Sedangkan agama mengacu pada yang bersifat formal dan diakui secara hukum, yang meliputi agama Islam, Katolik, Kristen, Budha, dan Hindu.

Tokoh dalam novel diceritakan sebagai penganut agama mayoritas di Bali. Agama tersebut yang dimaksud adalah Hindu Bali. Bagi tokoh dalam cerita, agama di Bali adalah yang sudah dianut oleh leluhurnya. Bahkan menganggapnya sebagai agama yang lebih dari yang lain.

\section{Kesenian}

Istilah kesenian menurut Kamus Besar Bahasa Indonesia (2005) adalah suatu karya yang diciptakan dengan keahlian yang luar biasa. Dalam kaitannya dengan kebudayaan, kesenian merupakan erat hubungannya dengan unsurunsurnya. Sehubungan dengan itu maka kesenian ini erat hubungannya dengan seni patung, relief, lukis dan gambar, vokal, musik, bangunan, kesusastraan, dan drama. Secara sederhana kesenian dapat diartikan sebagai segala hasrat manusia terhadap keindahan bentuk. Keindahan yang beraneka ragam itu timbul dari permainan imajinasi kreatif yang dapat memberikan kepuasan batin bagi manusia. Secara garis besar, kita dapat memetakan bentuk kesenian dalam tiga garis besar, yaitu seni rupa, seni suara dan seni tari.

Secara definitif keseluruhan karya seni jelas didominasi oleh aspek-aspek keindahan. Dengan kalimat lain, tujuan karya seni adalah menampilkan aspekaspek keindahan. Ada dugaan kuat bahwa pada awalnya karya seni tari lahir sebagai sarana upacara ritual dengan tujuan untuk memberikan pujian terhadap arwah para leluhur dan makhluk adikodrati lain. Dalam perkembangan berikutnya dengan memberikan kemasan yang lebih baru yaitu dengan puji-pujian yang dikaitkan dengan sistem religi. Hal ini tampak unsur seni dalam tradisi keagamaan di Bali yaitu seni tari, seni musik, maupun seni rupa (Ratna, 2011: 420). Unsur seni tersebut sangat menonjol sehingga upacara sangatlah meriah, agung, dan sacral

Unsur kesenian, dalam unsur budaya digunakan sebagai daya pikat oleh masyarakat Bali, bahkan digunakan sebagai komoditas pariwisata. Dari bukti 
tersebut di atas jelaslah bahwa kesenian erat kaitannya dengan keadaan masyarakat Bali.

\section{SIMPULAN}

Berdasarkan analisis yang telah dilakukan, Novel Sukreni Gadis Bali karya AA Pandji Tisna, dapat diambil kesimpulan sebagai berikut:

1. Terdapat nilai-nilai budaya dalam novel Sukreni Gadis Bali. Nilai budaya tersebut yaitu yang berhubungan dengan adat-istiadat masyarakat setempat. Adapun nilai budaya yang berhasil penulis temukan adalah: a) Nilai budaya tentang kesopanan, b) Nilai budaya tentang bekerja sama atau gotong royong, c) Nilai budaya tentang anggapan minum sebelum bekerja, d) Nilai budaya tentang menghormati orang lain dengan minum kopi, e) Nilai budaya tentang menyelesaikan pekerjaan secara tuntas, f) Nilai budaya tentang kesopanan sebelum nikah tidak boleh bermalam bersama, g) Nilai budaya tentang musyawarah bukan berdasar isu, h) Nilai budaya tentang menghargai orang lain sebagai saudara, h) Nilai budaya tentang tanggung jawab karena dipercaya mencari orang yang dipercayakan yaitu Ni Sukreni pada I Sudiana, i) Nilai budaya tentang mengubah kebiasaan tidak secara mendadak, j) Nilai budaya tentang penguatan kepada orang yang menderita atau silih - asih

2. Terdapat fakta sosial dalam novel Sukreni Gadis Bali karya AA. Pandji Tisna. Adapun fakta sosial yang berhasil penulis temukan adalah sebagai berikut: a) Ngaben, b) Kelian, c) Kain Santeng, d) Bayuan, e) Panggilan Jero, dan f) Sebutan Ratu

3. Terdapat kaitan antara nilai budaya dengan fakta sosial novel Sukreni Gadis Bali karya AA. Pandji Tisna. Hal ini dapat dilihat melalui unsur-unsur budaya dalam novel ini, berkaitan dengan fakta sosial masyarakatnya.

\section{DAFTAR PUSTAKA}

Depdiknas. (2005). Kamus besar bahasa Indonesia. Ed. Ketiga. Jakarta: Balai Pustaka.

Dewi, H. (2015). Nilai religius, moral, dan etika pada cerpen: Hubungan manusia dengan Ciptaannya. Jakarta: Unindra

Esarpit, R. (2017). Sosiologi sastra. Jakarta: Obor.

Luxemburg, J.V., dkk. (1991). Pengantar ilmu sastra. Jakarta: Gramedia.

Nurgiyantoro, B. (2015). Teori pengkajian fiksi. Cet.11. Yogyakarta: Gajahmada University Press

Pradopo, R. D. (2011). Pengkajian puisi. Yogyakarta: UGM Press

Ratna, N. K. (2011). Antropologi sastra: Peranan unsur-unsur kebudayaan dalam proses kreatif. Yogyakarta: Pustaka Pelajar

Sumardjo, J. (1982). Novel indonesia mutakhir: Sebuah kritik. Yogyakarta: CV Nur Cahya

Sumardjo, J. (1986). Apresiasi kesusastraan. Jakarta: Gramedia 
Diskursus: Jurnal Pendidikan Bahasa Indonesia

Vol. 2, No. 3, Desember 2019, pp. 204-215

p-ISSN: 2615-4935

e-ISSN: 2615-4943

Tisna. A A. P. (2013). Sukraeni Gadis Bali. Cet. 26. Jakarta: Balai Pustaka.

Suhardjo, C. M. K. (2003). Berbagi cara pendidikan gizi. Jakarta: Bumi Aksara.

Suryabrata, S. (2007). Psikologi pendidikan (Suatu pengajaran secara operasional. Yogyakarta: Rake Press. 